\title{
Methanoregula boonei gen. nov., sp. nov., an acidiphilic methanogen isolated from an acidic peat bog
}

\author{
Suzanna L. Bräuer, ${ }^{1} \dagger$ Hinsby Cadillo-Quiroz, ${ }^{1} \ddagger$ Rebekah J. Ward, ${ }^{1} \S$ \\ Joseph B. Yavitt ${ }^{2}$ and Stephen H. Zinder ${ }^{1}$ \\ ${ }^{1}$ Department of Microbiology, Cornell University, Ithaca, NY 14853, USA \\ ${ }^{2}$ Department of Natural Resources, Cornell University, Ithaca, NY 14853, USA
}

Correspondence

Stephen H. Zinder shz1@cornell.edu

\begin{abstract}
A novel acidiphilic, hydrogenotrophic methanogen, designated strain $6 \mathrm{~A}^{\top}$, was isolated from an acidic ( $\mathrm{pH} 4.0-4.5)$ and ombrotrophic (rain-fed) bog located near lthaca, NY, USA. Cultures were dimorphic, containing thin rods $(0.2-0.3 \mu \mathrm{m}$ in diameter and 0.8-3.0 $\mu \mathrm{m}$ long) and irregular cocci (0.2-0.8 $\mu \mathrm{m}$ in diameter). The culture utilized $\mathrm{H}_{2} / \mathrm{CO}_{2}$ to produce methane but did not utilize formate, acetate, methanol, ethanol, 2-propanol, butanol or trimethylamine. Optimal growth conditions were near $\mathrm{pH} 5.1$ and $35^{\circ} \mathrm{C}$. The culture grew in basal medium containing as little as $0.43 \mathrm{mM} \mathrm{Na}^{+}$and growth was inhibited completely by $50 \mathrm{mM} \mathrm{NaCl}$. To our knowledge, strain $6 \mathrm{~A} 8^{\top}$ is one of the most acidiphilic (lowest $\mathrm{pH}$ optimum) and salt-sensitive methanogens in pure culture. Acetate, coenzyme M, vitamins and yeast extract were required for growth. It is proposed that a new genus and species be established for this organism, Methanoregula boonei gen. nov., sp. nov. The type strain of Methanoregula boonei is $6 \mathrm{~A}^{\top}\left(=\mathrm{DSM} 21154^{\top}=\mathrm{JCM} 14090^{\top}\right)$.
\end{abstract}

$\mathrm{H}_{2} / \mathrm{CO}_{2}$-utilizing methanogens of the order Methanomicrobiales are found in diverse environments and have been isolated from oil wells (Ollivier et al., 1997), estuaries and marine sediments (Blotevogel et al., 1986; Chong et al., 2002; Mikucki et al., 2003; Rivard et al., 1983), anaerobic digesters (Ollivier et al., 1985; Paynter \& Hungate, 1968; Zellner et al., 1998), rumen fluid (Paynter \& Hungate, 1968), lakes and other freshwater systems (Franzmann et al., 1997; Harris et al., 1984) and as endosymbionts of ciliate protists (Van Bruggen et al., 1986). In the past 10 years, many novel members of the Methanomicrobiales have been described, including three new genera, Methanocalculus (Ollivier et al., 1998), Methanolinea (Imachi et al., 2008) and Methanosphaerula (CadilloQuiroz et al., 2009).

Culture-independent environmental surveys of acidic ( $\mathrm{pH}$ 3.5-5.0) peat-forming wetlands revealed an abundance

Abbreviation: SSU, small subunit.

†Present address: Department of Biology, Appalachian State University, Boone, NC 28608, USA.

‡Present address: Department of Microbiology, University of Illinois at Urbana-Champaign, Urbana, IL 61801, USA.

§Present address: Department of Microbiology and Immunology, Emory University School of Medicine, Atlanta, GA 30322, USA.

The GenBank/EMBL/DDBJ accession numbers for the $16 \mathrm{~S}$ rRNA gene sequence and complete genome sequence of strain $6 A 8^{\top}$ are DQ282124 and CP000780. The NCBI Protein accession number for the deduced McrA sequence is ABS55100. of mcrA and small-subunit (SSU) or 16S rRNA gene sequences that cluster in the Methanomicrobiales, sometimes considered related to Methanospirillum, but divergent from all methanogens in pure culture (Basiliko et al., 2003; Galand et al., 2002; Hales et al., 1996). These results have been supported using terminal restriction fragment length polymorphism (T-RFLP) profiles (Cadillo-Quiroz et al., 2006) or studies of mixed methanogenic cultures (Bräuer et al., 2006b; Horn et al., 2003; Sizova et al., 2003). Recently, an acidiphilic isolate, given the tentative name 'Candidatus Methanoregula boonei' 6A8 (Bräuer et al., 2006a), was obtained from one of the enrichment cultures. This organism had the unusual features of being dimorphic, with both rods and cocci, and acidiphilic, with a $\mathrm{pH}$ optimum near 5. Recently, the complete genome sequence of this organism was determined. In this communication, we present a complete taxonomic description of strain $6 \mathrm{~A} 8^{\mathrm{T}}$.

Enrichment of an acidiphilic methanogenic culture from McLean bog, an acidic ( $\mathrm{pH} 4.0-4.5$ ) and ombrotrophic (rain-fed) site near Ithaca, NY, USA (42 $\left.30^{\prime} \mathrm{N} 76^{\circ} 30^{\prime} \mathrm{W}\right)$ (Bräuer et al., 2004), followed by the isolation of the methanogenic strain $6 \mathrm{~A}^{\mathrm{T}}$ (Bräuer et al., 2006a) were described previously. The $6 \mathrm{~A} 8^{\mathrm{T}}$ culture was maintained on $\mathrm{H}_{2} / \mathrm{CO}_{2}$ in a modified PM1 low-ionic-strength basal medium (Bräuer et al., 2006a) amended with titanium(III) nitrilotriacetate [Ti(III) NTA], HOMOPIPES buffer [homopiperazine- $N, N^{\prime}$-bis-2-(ethanesulfonic acid), $5 \mathrm{mM}, \mathrm{pH}$ 5.4], coenzyme M (2-mercaptoethanesulfonic acid), sodium acetate, yeast extract and a vitamin solution. Cultures were 
incubated on a gyratory shaker at $28{ }^{\circ} \mathrm{C}$ and 200 r.p.m. As described elsewhere (Bräuer et al., 2006a), culture purity was verified by several tests including lack of heterotrophic growth, fluorescence in situ hybridization with a speciesspecific probe, lack of a PCR amplicon using bacterial $16 \mathrm{~S}$ rRNA gene primers and homogeneity of clone libraries of PCR amplicons based on two different archaeal primer sets.

DNA $G+C$ content was determined from the complete genome sequence. A phylogenetic analysis of the SSU rRNA gene sequence relative to other sequences from methanogens across all five methanogen orders, including closely related environmental sequences, has been presented elsewhere (Bräuer et al., 2006a). Here, we constructed a phylogenetic tree that includes primarily sequences from cultured and named members of the order Methanomicrobiales, allowing a more in-depth look at the phylogenetic placement of $6 \mathrm{~A} 8^{\mathrm{T}}$ among other members of the Methanomicrobiales. Additionally, we included several isolates and clone sequences from mixed cultures, as well as some environmental sequences from peatlands in the E1/ E2 group (Cadillo-Quiroz et al., 2006). Sequences of representative members of the Methanomicrobiales were aligned using the Silva database, release 94 (09.04.08), of the ARB package (Ludwig et al., 2004). Phylogenetic trees were constructed from $1212 \mathrm{bp}$ well-aligned sequences using neighbour-joining and maximum-likelihood methods in the PHYLIP software package (Felsenstein, 2004). The topologies of the two phylograms were identical for nodes with bootstrapping values $>70 \%$, and the neighbourjoining output is presented here. Methyl-coenzyme M reductase alpha subunit amino acid sequences, predicted from $m c r A$ gene sequences, were aligned using CLUSTAL_X (Thompson et al., 1997). Phylogenetic trees were constructed from 236 aligned amino acid positions using neighbour-joining and maximum-likelihood methods in the PHYLIP software package (Felsenstein, 2004). The branching pattern in the maximum-likelihood analysis was identical to that in the neighbour-joining analysis.

The following substrates for methanogenesis were added individually to cultures of strain $6 \mathrm{~A} 8^{\mathrm{T}}$ : sodium acetate, sodium formate ( $\mathrm{pH} \mathrm{5)}$ (both at $2 \mathrm{mM}$ ), methanol, ethanol, 2-propanol, butanol and trimethylamine (all at $5 \mathrm{mM}$ ). Cells were grown under a $\mathrm{N}_{2} / \mathrm{CO}_{2}$ atmosphere to test for substrate utilization and parallel tubes were grown under a $\mathrm{H}_{2} / \mathrm{CO}_{2}$ atmosphere to verify that the amount of substrate added was not inhibitory. Additionally, cultures were grown under a $\mathrm{H}_{2} / \mathrm{CO}_{2}$ atmosphere or under a $\mathrm{N}_{2} /$ $\mathrm{CO}_{2}$ atmosphere with no added substrate to serve as positive and negative controls, respectively. Growth rates, as determined by methanogenesis (Boone \& Whitman, 1988), were examined with respect to $\mathrm{Na}^{+}$concentration. For experiments on the effect of $\mathrm{Na}^{+}$, the medium was modified to limit the total $\mathrm{Na}^{+}$concentration. The $\mathrm{pH}$ of the HOMOPIPES buffer and Ti(III) NTA solutions was adjusted using $\mathrm{KOH}$ rather than $\mathrm{NaOH}$, and potassium acetate rather than sodium acetate was used, so that coenzyme M (which can only be purchased as the sodium salt) and yeast extract were the only known sources of $\mathrm{Na}^{+}$ in the medium. The final $\mathrm{Na}^{+}$concentration of the medium was determined to be $0.432 \pm 0.007 \mathrm{mM}$ by the Cornell Nutrient Analysis Laboratory using inductively coupled plasma (ICP) spectroscopy. Methane production by cultures was quantified using a flame ionization gas detector as described previously (Bräuer et al., 2004). Growth yield was determined in triplicate by drying $120 \mathrm{ml}$ culture on pre-weighed $0.2 \mu \mathrm{m}$ polycarbonate filters (Nucleopore) first on the bench top and then in a desiccator overnight. Uninoculated medium was filtered onto membranes (in triplicate) to calculate the blank. Specific growth rates $(\mu)$ were determined using the equation $\mu=\left(\ln \mathrm{X}-\ln \mathrm{X}_{0}\right) / t$ (Madigan et al., 2000). Physiological tests were performed in triplicate, and either standard deviation or standard error of the mean (where noted) was calculated.

For lipid analysis, cells were harvested in late exponential phase, centrifuged immediately and lyophilized before use. Extraction of total lipids and fractionation followed a procedure modified from Zhang et al. (2006). Analysis of the lipid components were conducted on an LC-MS as described previously (Sturt et al., 2004).

Microscopic analyses of cell motility and morphology were conducted under phase-contrast with a Nikon Eclipse E600 microscope. The cell envelope was tested using Gram staining and by evaluating susceptibility of the cells to SDS lysis, as described previously (Boone \& Whitman, 1988). Concentrations of $0,0.05,0.1,0.5,1,2$ and $3 \%$ SDS were used, and cell integrity was evaluated using microscopy. Negative-staining and thin-sectioning transmission electron microscopy was performed at the Cornell Integrated Microscopy Center. Cells were concentrated by centrifugation, washed and resuspended in deionized water. A drop $(\sim 5 \mu \mathrm{l})$ of the concentrated cells was mixed with a drop of bacitracin $\left(100 \mu \mathrm{g} \mathrm{ml}^{-1}\right)$ and allowed to settle onto Formvar-coated copper grids (100 mesh) for $5 \mathrm{~min}$ before staining with $2 \%$ uranyl acetate $(\mathrm{pH} 6.5)$ for a few seconds. The electron microscope used for low-resolution micrographs was a Phillips EM-201 equipped with a Gotan model 780 camera and that used for high-resolution micrographs was a Phillips Technai 12 Biotwin, equipped with a Gatan Multiscan model 791 camera and Digital Micrograph software. Photomicrographs were taken at $100 \mathrm{kV}$.

Cultures of strain $6 \mathrm{~A} 8^{\mathrm{T}}$ were dimorphic, consisting of thin, straight rods, $0.2-0.3 \mu \mathrm{m}$ in diameter and $0.8-3.0 \mu \mathrm{m}$ long, and irregular cocci, $0.3-0.8 \mu \mathrm{m}$ in diameter (Fig. 1; Bräuer et al., 2006a). Asymmetrical cell division was sometimes observed in rods, but cell division was not observed in cocci greater than $0.3 \mu \mathrm{m}$ in diameter (Bräuer et al., 2006a). In addition, two other mixed cultures containing organisms closely related to $6 \mathrm{~A} 8^{\mathrm{T}}(98-99 \%$ identity in the SSU rRNA gene), clone KB1 (S. H. Zinder, personal observation) and clone NTA (Bräuer et al., 2006b), also appear to be dimorphic. Using fluorescence microscopy, 
cofactor $\mathrm{F}_{420}$ autofluorescence was not observed in cells during any growth phase, indicating that the cells contained low concentrations of this cofactor, or possibly none. Transmission electron micrographs of negatively stained cell cultures of strain $6 \mathrm{~A} 8^{\mathrm{T}}$ (Fig. 1) showed that the two morphotypes had similar cell-wall structures that were visually identical to the S-layer cell envelopes found in most archaea (Kandler \& Konig, 1998). The two morphotypes had similar 'notches', which are attributed to fracturing of the S-layer by flattening of the cells during preparation. Filamentous appendages, $9-11 \mathrm{~nm}$ in diameter, were also observed, and some preparations contained darkly stained inclusions, which may have been storage granules. The diameters of the filaments are at the lower boundary of those for archaeal flagella (10-14 nm; Thomas et al., 2001), and, while archaeal flagella genes are present in the genome, motility of cells of $6 \mathrm{~A} 8^{\mathrm{T}}$ has not been observed. Thus, the function of the filaments is unknown. Cells were also sensitive to lysis by low concentrations of detergent ( $0.1 \%$ SDS $)$ and stained Gram-negative. These results suggest that strain $6 \mathrm{~A}^{\mathrm{T}}$ has a more typical archaeal proteinaceous S-layer that is more similar to that of Methanolinea tarda (Imachi et al., 2008) than to the thicker, SDS-resistant layer of Methanosphaerula palustris (Cadillo-Quiroz et al., 2009).

Strain $6 \mathrm{~A} 8^{\mathrm{T}}$ grows using $\mathrm{H}_{2} / \mathrm{CO}_{2}$ exclusively for methanogenesis. No growth or methane production was observed in the absence of $\mathrm{H}_{2} / \mathrm{CO}_{2}$ or upon addition of acetate, formate ( $\mathrm{pH}$ 5), methanol, ethanol (Bräuer et al., 2006a), 2-propanol, butanol or trimethylamine (this study). Acetate and formate at $2 \mathrm{mM}$ partially inhibited growth on $\mathrm{H}_{2} / \mathrm{CO}_{2}$ and were completely inhibitory at $5 \mathrm{mM}$. The other substrates did not inhibit methanogenesis significantly at $5 \mathrm{mM}$. Growth inhibition by $5 \mathrm{mM}$ acetate and formate may be partially explained by the toxicity of their protonated forms at low $\mathrm{pH}$ (Bräuer et al., 2004). Strain $6 \mathrm{~A} 8^{\mathrm{T}}$ also required $0.2 \mathrm{mM}$ acetate, coenzyme $\mathrm{M}$, vitamins

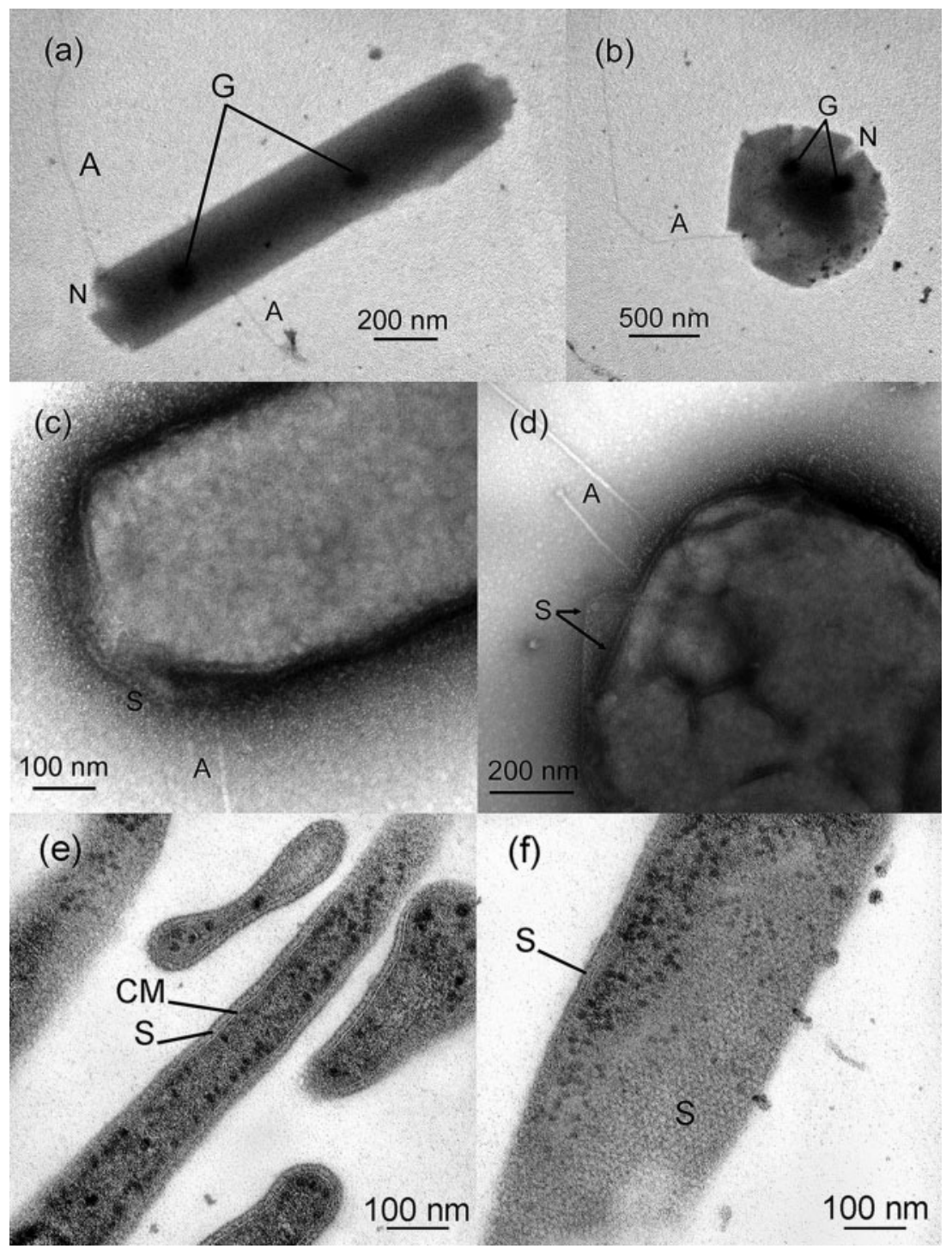

Fig. 1. Electron micrographs of strain $6 A 8^{\top}$ including uranyl acetate-stained rod-shaped $(a, c)$ and coccus-shaped ( $b, d)$ cells, as well as ultrathin-sectioned cells $(e, f)$. $(a, b)$ Lowresolution micrographs showing notches $(N)$ in the cell wall, putative storage granules $(G)$ and pilus-like appendages (A). (c, d) Higherresolution micrographs showing subunit structure at the periphery of the outer S-layer (S) and pilus-like appendages (A). (e, f) Ultrathinsection micrographs that highlight intercellular structures such as the outer S-layer (S) and cytoplasmic membrane (CM). Note the subunit structure of the $\mathrm{S}$-layer that is apparent in ( $\mathrm{f}$ ). 
Table 1. Characteristics of strain $6 \mathrm{~A}^{\top}$ and other representatives of the order Methanomicrobiales

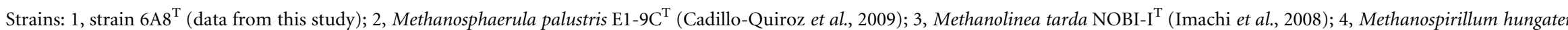

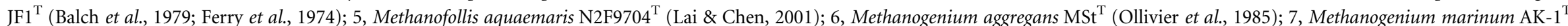

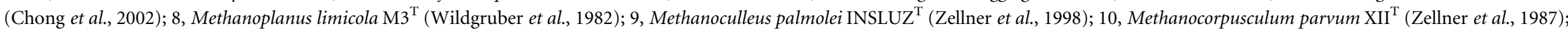
11, Methanocalculus halotolerans SEBR $4845^{\mathrm{T}}$ (Ollivier et al., 1998). All strains used $\mathrm{H}_{2} / \mathrm{CO}_{2}$ as a methanogenic substrate. ND, No data available.

\begin{tabular}{|c|c|c|c|c|c|c|c|c|c|c|c|}
\hline Characteristic & 1 & 2 & 3 & 4 & 5 & 6 & 7 & 8 & 9 & 10 & 11 \\
\hline Source & $\begin{array}{c}\text { Acidic } \\
\text { bog }\end{array}$ & $\begin{array}{r}\text { Rich } \\
\text { fen }\end{array}$ & $\begin{array}{l}\text { Sewage } \\
\text { sludge }\end{array}$ & $\begin{array}{l}\text { Sewage } \\
\text { sludge }\end{array}$ & $\begin{array}{l}\text { Fish } \\
\text { pond }\end{array}$ & $\begin{array}{c}\text { Anaerobic } \\
\text { digestor }\end{array}$ & $\begin{array}{l}\text { Marine } \\
\text { sediment }\end{array}$ & $\begin{array}{l}\text { Drilling } \\
\text { waste }\end{array}$ & $\begin{array}{c}\text { Anaerobic } \\
\text { digestor }\end{array}$ & $\begin{array}{c}\text { Anaerobic } \\
\text { digestor }\end{array}$ & $\begin{array}{l}\text { Oil } \\
\text { well }\end{array}$ \\
\hline $\begin{array}{l}\text { Cell shape* } \\
\text { pH for growth }\end{array}$ & TR, IC & $\mathrm{RC}$ & TR, F & S & RC, IC & IC & IC & $\mathrm{P}$ & IC & IC & IC \\
\hline Optimum & 5.1 & 5.7 & 7 & $6.6-7.4$ & 6.5 & $6.5-7$ & $6.0-6.6$ & $6.5-7.5$ & $6.9-7.5$ & $6.8-7.5$ & 7.6 \\
\hline Range & $4.5-5.5$ & $4.8-6.4$ & $6.7-8$ & ND & $6.3-8$ & $6-8$ & $5.5-7.5$ & ND & $6.5-8$ & ND & $7-8.4$ \\
\hline \multicolumn{12}{|l|}{$\begin{array}{l}\text { Temperature for } \\
\text { growth }\left({ }^{\circ} \mathrm{C}\right)\end{array}$} \\
\hline Optimum & $35-37$ & 30 & 50 & $30-37$ & 37 & 37 & 25 & 40 & 40 & 37 & 38 \\
\hline Range & $10-40$ & $14-35$ & $35-55$ & ND & $20-43$ & $25-40$ & $5-25$ & $17-41$ & $22-50$ & $25-44$ & $25-45$ \\
\hline \multicolumn{12}{|l|}{$\begin{array}{l}\mathrm{NaCl} \\
\text { concentration for } \\
\text { growth }(\%, \mathrm{w} / \mathrm{v})\end{array}$} \\
\hline Optimum & $<0.1$ & $<0.2$ & 0 & $\mathrm{ND}$ & 0.5 & ND & ND & 1 & $\mathrm{ND}$ & $0-4.7$ & 5 \\
\hline Range & $0-0.3$ & $0-0.6$ & $0-1.5$ & ND & $0-6$ & $0-2.5$ & $1.4-7.3$ & $0.4-5.4$ & $\mathrm{ND}$ & ND & $0-12.5$ \\
\hline Minimum $t_{\mathrm{gen}}(\mathrm{h})$ & 44 & 19 & 144 & 17 & 63 & 8 & 60 & 6 & 13.5 & 8 & 12 \\
\hline $\begin{array}{l}\text { DNA G }+\mathrm{C} \\
\text { content }(\mathrm{mol} \%)\end{array}$ & 54.5 & 58.9 & 56.3 & 45 & ND & 52 & $\mathrm{ND}$ & 47.5 & 59 & 49 & 55 \\
\hline \multicolumn{12}{|l|}{ Substrates used } \\
\hline Formate & - & + & + & + & + & + & + & + & + & + & + \\
\hline 2-Propanol & - & - & - & ND & - & ND & - & $\mathrm{ND}$ & + & + & - \\
\hline 2-Butanol & - & - & - & ND & - & $\mathrm{ND}$ & - & $\mathrm{ND}$ & + & + & - \\
\hline $\begin{array}{l}\text { Acetate required } \\
\text { for growth }\end{array}$ & + & + & + & + & - & + & + & + & ND & + & + \\
\hline
\end{tabular}

${ }^{*}$, Filaments; IC, irregular cocci; P, plate-shaped; RC, regular cocci; s, spirilla; TR, thin rods. 
and yeast extract for growth. Acetate is commonly used by methanogens as a carbon source, and is required by strains of many members of the Methanomicrobiales (Table 1), including Methanosphaerula palustris (Cadillo-Quiroz et al., 2009) and Methanospirillum hungatei (Sprott \& Jarrell, 1981). The growth yield on $\mathrm{H}_{2} / \mathrm{CO}_{2}$ was $0.68 \pm$ $0.13 \mathrm{~g}$ dry weight per mol methane and the maximum specific growth rate $(\mu)$ was $0.017 \mathrm{~h}^{-1}$ at $\mathrm{pH} 5.1$ and $28{ }^{\circ} \mathrm{C}$ (i.e. doubling time was $44 \pm 10 \mathrm{~h}$ ). Generation time $\left(t_{\mathrm{gen}}\right)$ was estimated to be 1.5-2 days during early exponential growth and 2-2.5 days during late exponential growth.

Strain $6 \mathrm{~A} 8^{\mathrm{T}}$ is a slow-growing methanogen with a maximum specific growth rate $(\mu)$ comparable to those of the moderate acidiphile Methanobacterium espanolae (approx. $0.022 \mathrm{~h}^{-1}$ at $\mathrm{pH} 5.6$ and $0.016 \mathrm{~h}^{-1}$ at $\mathrm{pH}$ 5.0; Patel et al., 1990) and the psychrophile Methanogenium frigidum $\left(0.014 \mathrm{~h}^{-1}\right.$; Franzmann et al., 1997). Another related strain of the Methanomicrobiales, Methanolinea tarda NOBI- $1^{\mathrm{T}}$, was reported to have an even lower $\mu$ of $0.007 \mathrm{~h}^{-1}$ (Imachi et al., 2008). Strain $6 \mathrm{~A} 8^{\mathrm{T}}$ had a temperature optimum for growth near $35{ }^{\circ} \mathrm{C}$, with no growth at 4 or $45{ }^{\circ} \mathrm{C}$ (Bräuer et al., 2006a). The $\mathrm{pH}$ optimum was near 5.1, and cultures did not grow below pH 4 or above $\mathrm{pH} 6$ (Bräuer et al., 2006a), making it a moderate acidiphile. Recently, Kotsyurbenko et al. (2007) isolated an acidiphilic Methanobacterium strain with a $\mathrm{pH}$ optimum between 5.0 and 5.5 and a growth range of $\mathrm{pH} 3.8-6.0$, similar to that of $6 \mathrm{~A} 8^{\mathrm{T}}$. It will be interesting to determine factors that regulate the distribution of these two acidiphilic methanogen groups. Overall, members of the E1/E2 group of the Methanomicrobiaceae, such as $6 \mathrm{~A} 8^{\mathrm{T}}$, are the predominant group in many temperate peatlands of various $\mathrm{pH}$ ranges throughout the world (Basiliko et al., 2003; Cadillo-Quiroz et al., 2006, 2008; Galand et al., 2003; Hales et al., 1996; Juottonen et al., 2005).

Peat bogs have low ion concentrations, and the $\mathrm{Na}^{+}$ concentration in McLean bog was near $2 \mu \mathrm{M}$ (Bräuer et al., 2004). A salient property of strain $6 \mathrm{~A}^{\mathrm{T}}$ is that it grew well at the lowest $\mathrm{Na}^{+}$concentration we could achieve in our growth medium, approx. $0.4 \mathrm{mM}$, and growth was inhibited almost completely by $50 \mathrm{mM} \mathrm{NaCl}$ (Fig. 2). Other hydrogenotrophic methanogens, even ones considered freshwater strains, tolerate much higher $\mathrm{NaCl}$ concentrations (Jarrell \& Kalmokoff, 1988), up to $250 \mathrm{mM}$. In addition, a requirement of about $1 \mathrm{mM} \mathrm{Na}^{+}$for growth (Perski et al., 1982) has been attributed to a bioenergetic circuit involving $\mathrm{Na}^{+}$pumping by a membrane-bound methyltetrahydromethoanopterin-coenzyme M methyltransferase (Deppenmeier et al., 1999). The low $\mathrm{Na}^{+}$ requirement of $6 \mathrm{~A}^{\mathrm{T}}$ and the low concentrations of $\mathrm{Na}^{+}$in the habitat from which it was isolated suggest a mechanism for energy conservation with a much higher affinity for $\mathrm{Na}^{+}$than is found in other methanogens, or one that does not involve $\mathrm{Na}^{+}$. In terms of $\mathrm{NaCl}$ tolerance, the recently described Methanosphaerula palustris was somewhat less sensitive, and did not tolerate $100 \mathrm{mM} \mathrm{NaCl}$ (CadilloQuiroz et al., 2009). This is not surprising, as Methanosphaerula

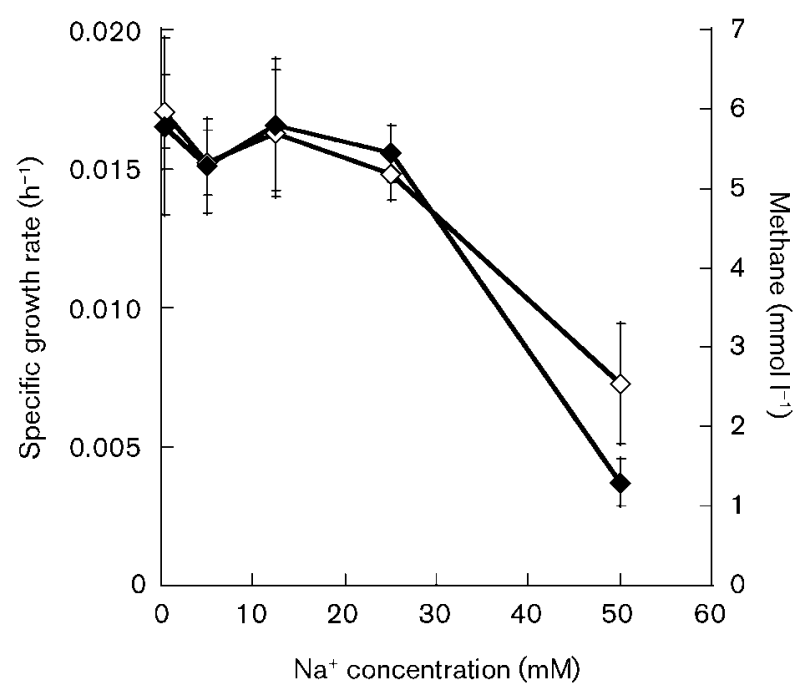

Fig. 2. Specific growth $(\diamond)$ and total $\mathrm{CH}_{4}$ production after 1 week $(\diamond)$ for cultures of strain $6 \mathrm{~A}^{\top}$ in response to a range of $\mathrm{NaCl}$ concentrations. Each point represents a mean of triplicate tubes and error bars represent SEM.

palustris was isolated from a neutral $\mathrm{pH}$ peatland with higher mineral nutrient concentrations. Growth of Methanolinea tarda, isolated from sewage sludge, was inhibited by $250-350 \mathrm{mM} \mathrm{NaCl}$ (Imachi et al., 2008), more typical of freshwater methanogens. Also, similar to Methanosphaerula palustris (Cadillo-Quiroz et al., 2009), strain $6 \mathrm{~A} 8^{\mathrm{T}}$ did not tolerate the millimolar concentrations of sulfide (Bräuer et al., 2006b) typically added as a reducing agent to growth media for methanogens.

The lipids of $6 \mathrm{~A} 8^{\mathrm{T}}$ were dominated by the non-cyclic glycerol dialkyl glycerol tetraether (GDGT-0) or caldarchaeol, which accounted for about $96 \%$ of the lipids. The other $4 \%$ of the lipids was composed mainly of diether archaeol. These results are consistent with archaeal lipids of other methanogens from the Methanomicrobiales (Koga et al., 1998).

Based upon phylogenetic analysis of SSU rRNA gene sequences, strain $6 \mathrm{~A}^{\mathrm{T}}$ (Bräuer et al., 2006a) was related to a clade of previously uncultured members of the Methanomicrobiales called the R10 group (Hales et al., 1996) or the E1/E2 group (Cadillo-Quiroz et al., 2006). This clade includes the two recently described species Methanolinea tarda (Imachi et al., 2008) and Methanosphaerula palustris (Cadillo-Quiroz et al., 2009). The sequence of the $\mathrm{mcrA}$ gene from the original $6 \mathrm{~A}$ enrichment culture (Bräuer et al., 2006b) placed it within the 'Fen cluster' in the Methanomicrobiales, demonstrating that this group is congruent with the SSU rRNA R10 or E1/E2 clade. The SSU rRNA gene sequence of strain $6 \mathrm{~A}^{\mathrm{T}}$ was close $(>98 \%$ identity) but not identical to many environmental sequences recovered from McLean bog and other acidic wetlands (Bräuer et al., 2006a, b). Fig. 3 shows the SSU 


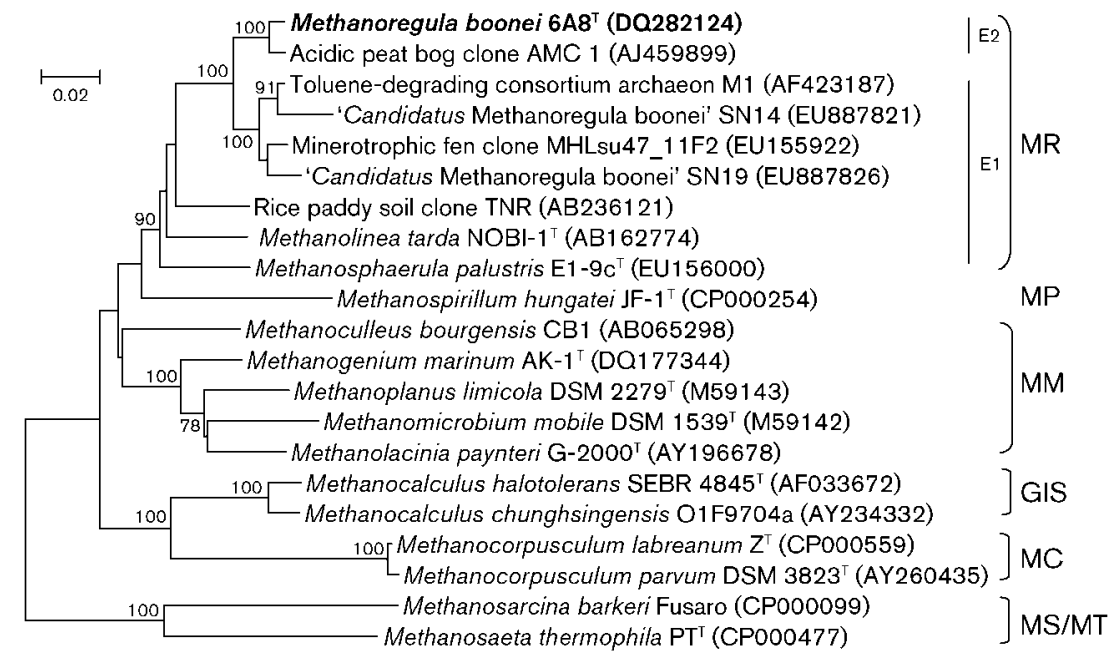

Fig. 3. Dendrogram showing the phylogenetic relationship of $16 \mathrm{~S}$ rRNA gene sequences from strain $6 A 8^{\top}$ and cultured members of families in the order Methanomicrobiales, as well as some uncultured members of group E1/E2. Families are abbreviated as follows: MM, Methanomicrobiaceae; MP, Methanospirillaceae; MC, Methanocorpusculaceae; GIS, genus incertae sedis; MS/MT, Methanosarcinaceae/Methanosaetaceae (Boone et al., 2001). Sequences of Methanosarcina barkeri Fusaro and Methanosaeta thermophila $\mathrm{PT}^{\top}$ were used as the outgroup. Alignments were performed in ARB (Ludwig et al., 2004) and the tree was constructed based on a distance-matrix analysis using the neighbour-joining method in the PHYLIP software package (Felsenstein, 2004). All nodes with bootstrapping values $>70 \%$ were supported using maximum-likelihood analysis. Bootstrapping values for those nodes are depicted here. Bar, 0.02 substitutions per nucleotide position.
rRNA gene phylogeny of selected members of the order Methanomicrobiales, including clone sequences from mixed cultures, clones AMC 1 and M1, the recently isolated 'Candidatus Methanoregula boonei' strains SN14 and SN19 (in pure culture) and two environmental clones, TNR and MHLsu47_11F2. Several representatives from mixed cultures, AMC 1 as well as clone NTA (GenBank accession no. DQ205188) and KB-1 (AY780566), share 98-99\% identity with $6 \mathrm{~A} 8^{\mathrm{T}}$. However, only AMC 1 was chosen for tree analysis because of the presence of a longer sequence in the database. 'Candidatus Methanoregula boonei' SN14 and SN19 sequences represent undescribed isolates from sewage sludge and share only $95 \%$ SSU rRNA gene sequence identity with strain $6 \mathrm{~A}^{\mathrm{T}}$. Both strains cluster more closely with members of group E1 and clearly represent different species, perhaps even a different genus from $6 \mathrm{~A} 8^{\mathrm{T}}$. Overall, phylogenetic analyses as well as physiological and structural characteristics support the placement of strain $6 \mathrm{~A} 8^{\mathrm{T}}$ in a novel genus and species, and perhaps a novel family (Fig. 4; Cadillo-Quiroz et al., 2009).

\section{Description of Methanoregula gen. nov.}

Methanoregula (Me.tha.no.re'gu.la. N.L. pref. methanopertaining to methane; L. fem. n. regula slat or ruler; N.L. fem. n. Methanoregula methane-producing thin slat).

Cells are dominated by thin rods and are commonly dimorphic, forming irregular cocci as well. Cultures are

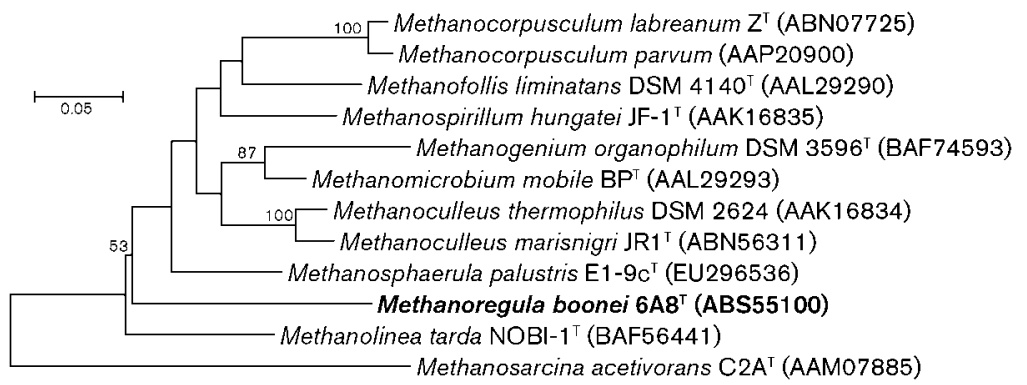

Fig. 4. Neighbour-joining dendrogram showing the phylogenetic relationship of the deduced McrA sequence from strain $6 \mathrm{~A}^{\top}$ with sequences from cultured members of the order Methanomicrobiales. The sequence of Methanosarcina acetivorans $\mathrm{C} 2 \mathrm{~A}^{\top}$ was used as the outgroup. Predicted amino acid sequences were aligned using CLUSTAL_X (Thompson et al., 1997). Phylogenetic trees were constructed from 236 aligned amino acids using neighbour-joining and maximumlikelihood methods in the PHYLIP software package (Felsenstein, 2004). The branching pattern in the maximum-likelihood analysis was identical to that in the neighbour-joining analysis. Nodes with bootstrapping values $>50 \%$ are presented here. Bar, 0.05 substitutions per amino acid position. 
mesophilic, produce methane from $\mathrm{H}_{2} / \mathrm{CO}_{2}$ and are strict anaerobes. Methanoregula boonei is the type species.

\section{Description of Methanoregula boonei sp. nov.}

Methanoregula boonei (boo'ne.i. N.L. masc. gen. n. boonei of Boone, to honour the pioneering work of David Boone on methanogenic archaea).

Displays the following properties in addition to those described for the genus. Cells occur as thin rods, dividing irregularly and sometimes producing longer rods, shorter rods or irregular cocci. They have a mean diameter of 0.2 $0.8 \mu \mathrm{m}$ and are non-motile, and many cells have pilus-like appendages. The cell envelope is composed of an SDSsensitive S-layer. Cells are obligately hydrogenotrophic. Grows at $\mathrm{pH}$ 4.5-5.5, with optimum growth near $\mathrm{pH}$ 5.1. Grows between 10 and $40{ }^{\circ} \mathrm{C}$, with an optimum near 35$37^{\circ} \mathrm{C}$. Cultures are also extremely salt sensitive, producing methane at exponential rates within a narrow salt range from $0.4 \mathrm{mM} \mathrm{Na}^{+}$to $25 \mathrm{mM} \mathrm{NaCl}$, and they are adapted to oligotrophic and low $\mathrm{pH}$ environments. Growth is inhibited by millimolar quantities of sulfide as a reducing agent, while $\mathrm{Ti}(\mathrm{III})$ and coenzyme $\mathrm{M}$ (2-mercaptoethanesulfonic acid) are tolerated. The genomic DNA G+C content of the type strain is $54.5 \mathrm{~mol} \%$, as determined from the genome sequence.

The type strain is $6 \mathrm{~A} 8^{\mathrm{T}}\left(=\mathrm{DSM} 21154^{\mathrm{T}}=\mathrm{JCM} 14090^{\mathrm{T}}\right)$.

\section{Acknowledgements}

We thank E. Angert and W. Ghiorse for microscopy advice, R. Davis for assistance with phylogenetic analyses and H. G. Trüper for advice on naming the organism. We also thank our collaborators for assistance with lipid analysis. Lipid extraction was performed in Chuanlun Zhang's laboratory (by Yige Zhang) at the University of Georgia and analysed in Kai Hinrichs' laboratory (by Xiaolei Liu) at the University of Bremen. This work was supported by the NSF Microbial Observatories Program (grant no. 0132049).

\section{References}

Balch, W. E., Fox, G. E., Magrum, L. J., Woese, C. R. \& Wolfe, R. S. (1979). Methanogens: reevaluation of a unique biological group. Microbiol Rev 43, 260-296.

Basiliko, N., Yavitt, J. B., Dees, P. M. \& Merkel, S. M. (2003). Methane biogeochemistry and methanogen communities in two northern peatland ecosystems, New York State. Geomicrobiol J 20, 563-577.

Blotevogel, K. H., Fischer, U. \& Lupkes, K. H. (1986). Methanococcus frisius sp. nov., a new methylotrophic marine methanogen. Can J Microbiol 32, 127-131.

Boone, D. R. \& Whitman, W. B. (1988). Proposal of minimal standards for describing new taxa of methanogenic bacteria. Int J Syst Bacteriol 38, 212-219.

Boone, D. R., Whitman, W. B. \& Koga, Y. (2001). Order II. Methanomicrobiales Balch and Wolfe 1981, 216 ${ }^{\mathrm{VP}}$. In Bergey's Manual of Systematic Bacteriology, 2nd edn, vol. 1, pp. 246-247. Edited by D. R. Boone, R. W. Castenholz \& G. M. Garrity. New York: Springer.
Bräuer, S. L., Yavitt, J. B. \& Zinder, S. H. (2004). Methanogenesis in McLean Bog, an acidic peat bog in upstate New York: stimulation by $\mathrm{H}_{2} / \mathrm{CO}_{2}$ in the presence of rifampicin, or by low concentrations of acetate. Geomicrobiol J 21, 433-443.

Bräuer, S. L., Cadillo-Quiroz, H., Yashiro, E., Yavitt, J. B. \& Zinder, S. H. (2006a). Isolation of a novel acidiphilic methanogen from an acidic peat bog. Nature 442, 192-194.

Bräuer, S. L., Yashiro, E., Ueno, N. G., Yavitt, J. B. \& Zinder, S. H. (2006b). Characterization of acid-tolerant $\mathrm{H}_{2} / \mathrm{CO}_{2}$-utilizing methanogenic enrichment cultures from an acidic peat bog in New York State. FEMS Microbiol Ecol 57, 206-216.

Cadillo-Quiroz, H., Bräuer, S. L., Yashiro, E., Sun, C., Yavitt, J. B. \& Zinder, S. H. (2006). Vertical profiles of methanogenesis and methanogens in two contrasting acidic peatlands in central New York State, USA. Environ Microbiol 8, 1428-1440.

Cadillo-Quiroz, H., Yashiro, E., Yavitt, J. B. \& Zinder, S. H. (2008). Characterization of the archaeal community in a minerotrophic fen and terminal restriction fragment length polymorphism-directed isolation of a novel hydrogenotrophic methanogen. Appl Environ Microbiol 74, 2059-2068.

Cadillo-Quiroz, H., Yavitt, J. B. \& Zinder, S. H. (2009). Methanosphaerula palustris gen. nov., sp. nov., a hydrogenotrophic methanogen isolated from a minerotrophic fen peatland. Int J Syst Evol Microbiol 59, 928-935.

Chong, S. C., Liu, Y., Cummins, M., Valentine, D. L. \& Boone, D. R. (2002). Methanogenium marinum sp. nov., a $\mathrm{H}_{2}$-using methanogen from Skan Bay, Alaska, and kinetics of $\mathrm{H}_{2}$ utilization. Antonie van Leeuwenhoek 81, 263-270.

Deppenmeier, U., Lienard, T. \& Gottschalk, G. (1999). Novel reactions involved in energy conservation by methanogenic archaea. FEBS Lett 457, 291-297.

Felsenstein, J. (2004). PHYLIP (phylogeny inference package), version 3.68. Distributed by the author. Department of Genome Sciences, University of Washington, Seattle, USA.

Ferry, J. G., Smith, P. H. \& Wolfe, R. S. (1974). Methanospirillum, a new genus of methanogenic bacteria and characterization of Methanospirillum hungatii sp. nov. Int J Syst Bacteriol 24, 465-469.

Franzmann, P. D., Liu, Y. T., Balkwill, D. L., Aldrich, H. C., deMacario, E. C. \& Boone, D. R. (1997). Methanogenium frigidum sp. nov., a psychrophilic, $\mathrm{H}_{2}$-using methanogen from Ace Lake, Antarctica. Int $J$ Syst Bacteriol 47, 1068-1072.

Galand, P. E., Saarnio, S., Fritze, H. \& Yrjala, K. (2002). Depth related diversity of methanogen Archaea in Finnish oligotrophic fen. FEMS Microbiol Ecol 42, 441-449.

Galand, P. E., Fritze, H. \& Yrjala, K. (2003). Microsite-dependent changes in methanogenic populations in a boreal oligotrophic fen. Environ Microbiol 5, 1133-1143.

Hales, B. A., Edwards, C., Ritchie, D. A., Hall, G., Pickup, R. W. \& Saunders, J. R. (1996). Isolation and identification of methanogenspecific DNA from blanket bog peat by PCR amplification and sequence analysis. Appl Environ Microbiol 62, 668-675.

Harris, J. E., Pinn, P. A. \& Davis, R. P. (1984). Isolation and characterization of a novel thermophilic freshwater methanogen. Appl Environ Microbiol 48, 1123-1128.

Horn, M. A., Matthies, C., Küsel, K., Schramm, A. \& Drake, H. L. (2003). Hydrogenotrophic methanogenesis by moderately acidtolerant methanogens of a methane-emitting acidic peat. Appl Environ Microbiol 69, 74-83.

Imachi, H., Sakai, S., Sekiguchi, Y., Hanada, S., Kamagata, Y., Ohashi, A. \& Harada, H. (2008). Methanolinea tarda gen. nov., sp nov., a methane-producing archaeon isolated from a methanogenic digester sludge. Int J Syst Evol Microbiol 58, 294-301. 
Jarrell, K. F. \& Kalmokoff, M. L. (1988). Nutritional requirements of the methanogenic archaebacteria. Can J Microbiol 34, 557-576.

Juottonen, H., Galand, P. E., Tuittila, E. S., Laine, J., Fritze, H. \& Yrjala, K. (2005). Methanogen communities and Bacteria along an ecohydrological gradient in a northern raised bog complex. Environ Microbiol 7, 1547-1557.

Kandler, O. \& Konig, H. (1998). Cell wall polymers in Archaea (Archaebacteria). Cell Mol Life Sci 54, 305-308.

Koga, Y., Morii, H., Akagawa-Matsushita, M. \& Ohga, I. (1998). Correlation of polar lipid composition with $16 \mathrm{~S}$ rRNA phylogeny in methanogens: further analysis of lipid component parts. Biosci Biotechnol Biochem 62, 230-236.

Kotsyurbenko, O. R., Friedrich, M. W., Simankova, M. V., Nozhevnikova, A. N., Golyshin, P. N., Timmis, K. N. \& Conrad, R. (2007). Shift from acetoclastic to $\mathrm{H}_{2}$-dependent methanogenesis in a west Siberian peat bog at low $\mathrm{pH}$ values and isolation of an acidophilic Methanobacterium strain. Appl Environ Microbiol 73, 2344-2348.

Lai, M. C. \& Chen, S. C. (2001). Methanofollis aquaemaris sp. nov., a methanogen isolated from an aquaculture fish pond. Int J Syst Evol Microbiol 51, 1873-1880.

Ludwig, W., Strunk, O., Westram, R., Richter, L., Meier, H., Yadhukumar, Buchner, A., Lai, T., Steppi, S. \& other authors (2004). ARB: a software environment for sequence data. Nucleic Acids Res 32, 1363-1371.

Madigan, M. T., Martinko, J. M. \& Parker, J. (2000). Brock: Biology of Microorganisms. Upper Saddle River, NJ: Prentice-Hall.

Mikucki, J. A., Liu, Y. T., Delwiche, M., Colwell, F. S. \& Boone, D. R. (2003). Isolation of a methanogen from deep marine sediments that contain methane hydrates, and description of Methanoculleus submarinus sp. nov. Appl Environ Microbiol 69, 3311-3316.

Ollivier, B. M., Mah, R. A., Garcia, J. L. \& Robinson, R. (1985). Isolation and characterization of Methanogenium aggregans sp. nov. Int J Syst Bacteriol 35, 127-130.

Ollivier, B., Cayol, J. L., Patel, B. K. C., Magot, M., Fardeau, M. L. \& Garcia, J. L. (1997). Methanoplanus petrolearius sp. nov., a novel methanogenic bacterium from an oil-producing well. FEMS Microbiol Lett 147, 51-56.

Ollivier, B., Fardeau, M. L., Cayol, J. L., Magot, M., Patel, B. K. C., Prensier, G. \& Garcia, J. L. (1998). Methanocalculus halotolerans gen. nov., sp. nov., isolated from an oil-producing well. Int J Syst Bacteriol 48, 821-828.

Patel, G. B., Sprott, G. D. \& Fein, J. E. (1990). Isolation and characterization of Methanobacterium espanolae sp. nov., a mesophilic, moderately acidophilic methanogen. Int J Syst Bacteriol 40, 12-18.

Paynter, M. J. \& Hungate, R. E. (1968). Characterization of Methanobacterium mobilis, sp. n., isolated from the bovine rumen. J Bacteriol 95, 1943-1951.
Perski, H.-J., Schönheit, P. \& Thauer, R. K. (1982). Sodium dependence of methane formation in methanogenic bacteria. FEBS Lett 143, 323-326.

Rivard, C. J., Henson, J. M., Thomas, M. V. \& Smith, P. H. (1983). Isolation and characterization of Methanomicrobium paynteri sp. nov., a mesophilic methanogen isolated from marine sediments. Appl Environ Microbiol 46, 484-490.

Sizova, M. V., Panikov, N. S., Tourova, T. P. \& Flanagan, P. W. (2003). Isolation and characterization of oligotrophic acido-tolerant methanogenic consortia from a Sphagnum peat bog. FEMS Microbiol Ecol 45, 301-315.

Sprott, G. D. \& Jarrell, K. F. (1981). $\mathrm{K}^{+}, \mathrm{Na}^{+}$, and $\mathrm{Mg}^{2+}$ content and permeability of Methanospirillum hungatei and Methanobacterium thermoautotrophicum. Can J Microbiol 27, 444-451.

Sturt, H. F., Summons, R. E., Smith, K., Elvert, M. \& Hinrichs, K. U. (2004). Intact polar membrane lipids in prokaryotes and sediments deciphered by high-performance liquid chromatography/electrospray ionization multistage mass spectrometry - new biomarkers for biogeochemistry and microbial ecology. Rapid Commun Mass Spectrom 18, 617-628.

Thomas, N. A., Bardy, S. L. \& Jarrell, K. F. (2001). The archaeal flagellum: a different kind of prokaryotic motility structure. FEMS Microbiol Rev 25, 147-174.

Thompson, J. D., Gibson, T. J., Plewniak, F., Jeanmougin, F. \& Higgins, D. G. (1997). The CLUSTAL_X windows interface: flexible strategies for multiple sequence alignment aided by quality analysis tools. Nucleic Acids Res 25, 4876-4882.

Van Bruggen, J. J. A., Zwart, K. B., Hermans, J. G. F., Van Hove, E. M., Stumm, C. K. \& Vogels, G. D. (1986). Isolation and characterization of Methanoplanus endosymbiosus sp. nov., an endosymbiont of the marine sapropelic ciliate Metopus contortus Quennerstedt. Arch Microbiol 144, 367-374.

Wildgruber, G., Thomm, M., Konig, H., Ober, K., Ricchiuto, T. \& Stetter, K. O. (1982). Methanoplanus limicola, a plate-shaped methanogen representing a novel family, the Methanoplanaceae. Arch Microbiol 132, 31-36.

Zellner, G., Alten, C., Stackebrandt, E., Demacario, E. C. \& Winter, J. (1987). Isolation and characterization of Methanocorpusculum parvum, gen. nov., spec. nov., a new tungsten requiring, coccoid methanogen. Arch Microbiol 147, 13-20.

Zellner, G., Messner, P., Winter, J. \& Stackebrandt, E. (1998). Methanoculleus palmolei sp. nov., an irregularly coccoid methanogen from an anaerobic digester treating wastewater of a palm oil plant in North-Sumatra, Indonesia. Int J Syst Bacteriol 48, 1111-1117.

Zhang, C. L., Pearson, A., Li, Y. L., Mills, G. \& Wiegel, J. (2006). Thermophilic temperature optimum for crenarchaeol synthesis and its implication for archaeal evolution. Appl Environ Microbiol 72, $4419-4422$. 